This is an electronic reprint of the original article. This reprint may differ from the original in pagination and typographic detail.

Please cite the original version:

S. Christel; Yu, CX; Wu, XF; Josefsson, S; Lillhonga, T; Högfors-Rönnholm, E; Sohlenius, G; Åström, ME; Dopson, M (2019). Comparison of boreal acid sulfate soil microbial communities in oxidative and reductive environments. Research in Microbiology, 170 (6-7) : 288-295. https://doi.org/10.1016/j.resmic.2019.06.002

doi: 10.1016/j.resmic.2019.06.002

URL: https://doi.org/10.1016/j.resmic.2019.06.002

CC BY NC ND 4.0 
Original Article

\title{
Comparison of boreal acid sulfate soil microbial communities in oxidative and reductive environments
}

\author{
Stephan Christel ${ }^{\mathrm{a},{ }^{*}, 1}$, Changxun $\mathrm{Yu}{ }^{\mathrm{b}, 1}$, Xiaofen $\mathrm{Wu}{ }^{\mathrm{a}}$, Sarah Josefsson ${ }^{\mathrm{c}}$, Tom Lillhonga ${ }^{\mathrm{d}}$, \\ Eva Högfors-Rönnholm ${ }^{\mathrm{d}}$, Gustav Sohlenius ${ }^{\mathrm{c}}$, Mats E. Åström ${ }^{\mathrm{b}}$, Mark Dopson ${ }^{\mathrm{a}}$ \\ ${ }^{a}$ Centre for Ecology and Evolution in Microbial Model Systems (EEMiS), Linnaeus University, SE-39182 Kalmar, Sweden \\ ${ }^{\mathrm{b}}$ Department of Biology and Environmental Science, Linnaeus University, SE-39182 Kalmar, Sweden \\ ${ }^{c}$ Geological Survey of Sweden, Box 670, 75128 Uppsala, Sweden \\ ${ }^{\mathrm{d}}$ Research and Development, Novia University of Applied Sciences, FI-65200, Vaasa, Finland
}

\section{A R T I C L E I N F O}

\section{Article history:}

Received 13 August 2018

Accepted 26 June 2019

Available online $\mathrm{xxx}$

\section{Keywords:}

Sulfide mineral

Metal

Sulfur

16S rRNA gene

Mitigation

Wetland

\begin{abstract}
A B S T R A C T
Due to land uplift after the last ice age, previously stable Baltic Sea sulfidic sediments are becoming dry land. When these sediments are drained, the sulfide minerals are exposed to air and can release large amounts of metals and acid into the environment. This can cause severe ecological damage such as fish kills in rivers feeding the northern Baltic Sea. In this study, five sites were investigated for the occurrence of acid sulfate soils and their geochemistry and microbiology was identified. The $\mathrm{pH}$ and soil chemistry identified three of the areas as having classical acid sulfate soil characteristics and culture independent identification of 16S rRNA genes identified populations related to acidophilic bacteria capable of catalyzing sulfidic mineral dissolution, including species likely adapted to low temperature. These results were compared to an acid sulfate soil area that had been flooded for ten years and showed that the previously oxidized sulfidic materials had an increased $\mathrm{pH}$ compared to the unremediated oxidized layers. In addition, the microbiology of the flooded soil had changed such that alkalinity producing ferric and sulfate reducing reactions had likely occurred. This suggested that flooding of acid sulfate soils mitigates their environmental impact.
\end{abstract}

(C) 2019 Institut Pasteur. Published by Elsevier Masson SAS. All rights reserved.

\section{Introduction}

Metal sulfide-rich sediments occur widely in many coastal areas surrounding the Gulf of Bothnia region of the Baltic Sea [1]. Since the last ice age, land uplift has resulted in these sediments rising above the sea level and due to the typically high economic value of coastal areas, being drained for e.g. infrastructure or agricultural uses. This exposes the previously stable and $\mathrm{pH}$-neutral 'potential acid sulfate soil materials' (PASS materials) [2,3] to air, allowing for their oxidation and turning them into acid sulfate soils (ASS) [4]. Oxidation of PASS material results in the release of acidic waters containing high concentrations of metals such as $\mathrm{Cd}, \mathrm{Ni}, \mathrm{Mn}$, and $\mathrm{Al}$ into receiving water bodies [5-7]. This causes severe environmental as well as economic damage and potentially impacts human health. The presence, environmental impact, and remediation of

\footnotetext{
* Corresponding author.

E-mail address: stephan.christel@Inu.se (S. Christel).

1 These authors contributed equally to this work.
}

Finnish ASS has been extensively studied [3,6,8-10]. However, only a few studies have been carried out on the presence and effect of ASS on the Swedish side of the Baltic Sea [11-14].

The oxidation of metal sulfides in PASS material (leading to ASS) is similar to the well studied generation of acid mine drainage from sulfide minerals and the commercial process of biomining $[15,16]$. In these processes, the metal sulfide bond is chemically oxidized by ferric iron to produce soluble metal(s) and depending on the type of mineral, either thiosulfate or elemental sulfur [17]. The mineral dissolution is catalyzed by acidophilic microorganisms (optimal pH for acidophile growth $<5$ and extreme acidophiles $<3$ ) that oxidize the ferrous iron to regenerate the chemical oxidant and convert the reduced sulfur to sulfuric acid. The acidophilic microorganisms responsible for catalyzing oxidation of PASS material have been studied in a boreal ASS profile at the Risöfladan experimental area, Vaasa, Finland where a mixture of populations related to either acid and metal contaminated sites or low temperature environments are present [4]. These acidophiles included Acidithiobacillus ferrivorans [18] that is a low temperature, ferrous iron and sulfur oxidizing acidophile [19-22]. However, there is a general lack of 
studies addressing the microbiology of PASS material and ASS and in particular, the acidophile community in relation to sulfide oxidation and acid generation in boreal settings is poorly understood.

The oxidation of PASS material to ASS typically results in layers within the soil with acidic, ferric iron bound oxidized materials close to the surface, with an oxidation horizon below, and then unoxidized PASS material in the deepest anoxic layers. Methods to halt oxidation of PASS material and consequently, the release of acidic, metal laden solutions to the environment include the addition of e.g. lime to raise the $\mathrm{pH}$ and inhibit the activity of acidophilic microbes [10] or organic compounds to promote sulfate and ferric iron reduction to raise the $\mathrm{pH}$ and bind the metals [8] as well as increasing the ground-water table to create an anaerobic environment that halts the oxidation [23]. In an Australian study on flooding coastal ASS, the distribution of sulfate and ferric iron reducing microbes overlapped and were controlled by factors including acidity, redox potential, and mineralization [24]. However, the effect of flooding boreal ASS on the acidophilic microbes present has not been reported.

In this study, five sites in northern Sweden were investigated for the presence of acid sulfate soils and community DNA extracted to identify the microbes present by culture free amplification of the 16S rRNA gene. In addition, the soils below a pond that was created to flood an ASS area was tested to identify how this affected the microbial community. This is the first microbiological study of Swedish ASS and also the first to address changes in a boreal ASS microbial community as a result of flooding.

\section{Materials and methods}

\subsection{Collection of samples and soil classification}

Six soils in northern Sweden were selected for the study. The sampling was carried out on 29th and 30th September 2016 using an extendable Edelmann corer. The soil profiles reached from the surface down into the reduced sulfidic (i.e. anoxic) sediment. The latter was identified by its blackish color and/or near neutral $\mathrm{pH}$ that was measured in-field every $10 \mathrm{~cm}$ with a Hamilton 340i pH/ Conductivity Pocket Meter with a flatrode electrode (Supplementary File 1 ). The definition of PASS material is a field $\mathrm{pH} \geq 6.0$ and a $\mathrm{pH} \leq 4.0$ after a 9-week-incubation in the laboratory, and the soils were classified as an ASS if its $\mathrm{pH}$ was either $<4.0$ or $<4.5$ if the underlying deposit was classified as PASS material. Ånäset (N 64 $16^{\prime} 8.51^{\prime \prime}$, E $21^{\circ} 2^{\prime} 1.43^{\prime \prime}$ ) and Flarkbäck (N 64 $17^{\prime} 5.43^{\prime \prime}$, E $\left.20^{\circ} 55^{\prime} 42.04^{\prime \prime}\right)$ are sites representative of classical boreal ASS formed as a result of farmland drainage. These soils contained blackish sulfidic material at the bottom (PASS material) and had $\mathrm{pH}$ values $<4.5$ at depths of 50-160 and $60-160 \mathrm{~cm}$, respectively (Supplementary File 1). The Vebomark pond (N 64 $24^{\prime} 17.13^{\prime \prime}, \mathrm{E}$ $21^{\circ} 1^{\prime} 6.57^{\prime \prime}$ ) and Vebomark site (N 64 $24^{\prime} 15.10^{\prime \prime}$, E $21^{\circ} 1^{\prime} 10.10^{\prime \prime}$ ) are also located in an area with ASS. The pond site represents a soil that has been covered with a 1.2-m-thick soil layer to create an artificial island in the pond leading to the ASS becoming submerged and its profile was blackish at the bottom with a $\mathrm{pH}<4.5$ at $160 \mathrm{~cm}$. The Vebomark site is located in a field nearby the pond and its deepest parts were not blackish but had an incubation pH of 3.2 and from 70 to $120 \mathrm{~cm}$ a pH mainly $<4.5$ (Supplementary File 1). The fifth site, Bygdeå (N 64 $3^{\circ} 27.83^{\prime \prime}, \mathrm{E}$ $20^{\circ} 52^{\prime} 16.58^{\prime \prime}$ ), was chosen since the wetland at this site is thought to be underlain with ASS and is planned to be restored by increasing the ground water table. However, although the deepest parts of the soil had an incubation $\mathrm{pH}$ well below 4.0, it did not have a $\mathrm{pH}<4.5$ except in the plough layer and was therefore not classified as an ASS (Supplementary File 1). Finally, Kålboda (N 64 $22^{\prime} 57.64^{\prime \prime}$, E $20^{\circ} 55^{\prime} 26.01^{\prime \prime}$ ) was selected as a reference as it is a farmland site underlain with non-sulfidic fine-grained sediments. This soil had a $\mathrm{pH}$ value $>4.5$ throughout its depth profile (Supplementary Fig. 1) and was therefore not an ASS.

Single replicate samples for detailed chemical and microbiological analysis were taken from the PASS material as well as from several depths in the ASSs and in the Kålboda and Bygdeå non-ASS profiles (Supplementary Fig. 1). Samples were collected from Ånäset between 50 and $180 \mathrm{~cm}$ below the surface (four samples designated as An-50 to An-180); Bygdeå (five samples; By-30 to By220); Flarkbäck (five samples; Fl-50 to Fl-220); Kålaboda (four samples; Ka-50 to Ka-220); Vebomark (six samples; Ve-50 to Ve220); and Vebomark Pond (five samples; VePo-130 to VePo-230; the uppermost $1.2 \mathrm{~m}$ artificial material was not sampled). The microbiological samples were collected aseptically and stored on ice until returned to the laboratory (within $36 \mathrm{~h}$ ) where they were frozen until analysis.

\subsection{Chemical analysis}

In the laboratory, the samples were dried, pulverized, and analyzed for $\mathrm{Co}, \mathrm{Cr}, \mathrm{Ni}, \mathrm{Zn}$, and Mn concentrations by inductively coupled plasma mass spectrometry (ICP-MS; PerkinElmer) after extraction of $2 \mathrm{~g}$ soil material with $10 \mathrm{~mL} 7 \mathrm{M} \mathrm{HNO}_{3}$ for $40 \mathrm{~min}$ at $115{ }^{\circ} \mathrm{C}$. Additionally, total sulfur concentration was measured with inductively coupled plasma optical emission spectometry (ICPOES). Total carbon (TC) and total organic carbon (TOC) contents were measured using a LECO TruMac at the Department of Soil and Environment, Swedish University of Agricultural Sciences. Total inorganic carbon (TIC) content was calculated as the difference between TC and TOC contents.

\subsection{DNA extraction, amplification, sequencing, and analysis}

To avoid extraction and amplification of extracellular DNA bound to the soil particles, intact cells were separated from the soil particles according to Alavi et al. [25] and adapted by HögforsRönnholm et al. [8,26]. DNA was extracted using the PowerSoil DNA Isolation Kit and the concentrations quantified with a Qubit fluorometer (Invitrogen).

Total community DNA was amplified in a two-step PCR whereby the first amplification was carried out using primers 341F and $805 \mathrm{R}$ targeting the V3-V5 region of the 16S rRNA gene [27] and then individual tags attached for Illumina sequencing according to Hugerth et al. [28]. Library preparation and sequencing was carried out at the Science for Life Laboratory, Stockholm, Sweden on the Illumina MiSeq platform to provide $2 \times 300$ bp pair-end sequences [29]. Bioinformatic analysis was performed using the UPARSE pipeline [30], OTUs annotated against the SINA/SILVA database (SILVA 119; [31]), and data interpreted in R 3.4.2 using the phyloseq package (v1.20) [32]. The presented 16S rRNA data are relative abundances and hence compositional in nature. Therefore, the multivariate structure of the data is analyzed using the compositional version of PCA (CoDaPCA) described in Högfors-Rönnholm et al. [33]. Maximum likelihood phylogenetic trees were constructed in MEGA7 [34]. The nucleic acid data is available in the NCBI database with the BioProject accession number: PRJNA420211.

\section{Results and discussion}

\subsection{Geochemical characteristics}

The Ånäset and Flarkbäck profiles were typical ASS developed on sulfidic clay/silt sediments. Both of the profiles contained well- 
developed acidic layers (An-80 and An-120 plus Fl-110 and Fl-140) with low $\mathrm{pH}(>4)$ and relatively low total sulfur concentrations, likely caused by sulfide oxidation followed by sulfate leaching $[4,35]$. Additionally, these two profiles showed typical trace-metal losses (via leaching) in the acidic layers as compared to the PASS material (An-180, Fl-220), in particular for Co, Ni, Zn, and $\mathrm{Mn}$ (Table 1). The clay/silt profile from Vebomark pond that had been covered with a $1.2-\mathrm{m}$-thick soil layer and been entirely under water (below the groundwater table) for ten years was, in terms of sulfur and trace-metal ( $\mathrm{Co}, \mathrm{Ni}, \mathrm{Zn}$, and $\mathrm{Mn}$ ) patterns, very similar to Ånäset and Flarkbäck (Table 1). However, Vebomark pond had higher $\mathrm{pH}$ values (>4.3). This indicated alkalinity-producing reactions, such as reduction of sulfate and ferric iron phases, might have occurred during the ten-year-long waterlogging.

The clay/silt profile at Kålaboda, which was not an ASS, had throughout the depth profile low sulfur concentrations $(0.01-0.05 \%)$ and relatively high $\mathrm{pH}(5.2-6.2)$. The three uppermost samples for detailed analyses (Ka-50, Ka-80, and Ka-110) were however weakly acidic ( $\mathrm{pH} 5.2-5.6$ ) and had, consistent with the ASS, lower trace-metal ( $\mathrm{Co}, \mathrm{Ni}, \mathrm{Zn}$, and $\mathrm{Mn}$ ) concentrations than the deepest sample (Ka-120) with a pH of 6.2 and slightly elevated sulfur concentrations (Table 1 ). Therefore, it is possible that some metal-sulfide oxidation and associated sulfur and trace-metal mobilization and leaching had also occurred in this profile. The relatively high $\mathrm{pH}$ of this profile was not due to enhanced buffering from carbonate phases, as TIC was very low in this profile (Table 1). The remaining two profiles (Vebomark and Bygdeå) were more difficult to interpret from a geochemical point of view, as they had clay/silt material overlying coarser (sandy) material (Table 1 ). This was most likely caused by inherent geochemical heterogeneity, as indicated by the distribution pattern of chromium which is an excellent tracer for assessment of geochemical homogeneity of ASS [36]. In the sandy samples (i.e. By-70 and By-100 plus Ve-140, Ve160 , and Ve-190), chromium was $<22 \mathrm{ppm}$ and in the clay/silt samples 26-39 ppm (Table 1). As a comparison, chromium was very stable in the other four clay/silt profiles with values between 32 and 38 ppm. The Vebomark and Bygdeå profiles had sulfur concentrations that varied but were overall higher than in Kålaboda.

\subsection{Microbiological characterization}

Sequencing of the soil microbiome resulted in 4250 to 408,596 merged reads per sample (mean: 96,134 ; Supplementary Table 1), of which on average $1.86 \%$ were filtered as they did not meet quality criteria. Clustering based on $97 \%$ sequence identity revealed a total of 6630 operational taxonomic units (OTUs).

Alpha diversity analysis with Shannon's H index on the OTUs did not give any clear patterns between the samples, sample depths, or $\mathrm{pH}$ (Supplementary Fig. 2). This suggested that although the populations changed with the different conditions, the extreme acidity in the ASS did not inhibit the growth of a diverse population of microorganisms. At the family level, there was a general increase in the relative proportion of 16S rRNA gene sequences most similar to uncultured clones with increasing depths in the soil profiles (Fig. 1 \& Supplementary Fig. 3). Although the bacterial primer set used in this study is also reported to have amplified archaeal sequences [37,38], in contrast to

Table 1

Physical and chemical analyses (single samples were analyzed) of the soil profiles from the six sampling sites.

\begin{tabular}{|c|c|c|c|c|c|c|c|c|c|c|c|}
\hline \multirow[t]{2}{*}{ Sample name } & \multirow[t]{2}{*}{ Sample depth $(\mathrm{cm})$} & \multirow[t]{2}{*}{ Soil type } & \multirow[t]{2}{*}{$\mathrm{pH}$ (field) } & \multirow[t]{2}{*}{$\mathrm{S}(\%)$} & \multirow[t]{2}{*}{$\operatorname{TIC}(\%)$} & \multirow[t]{2}{*}{ Organic C (\%) } & \multicolumn{5}{|c|}{ Metal concentrations (ppm) } \\
\hline & & & & & & & Co & $\mathrm{Cr}$ & Mn & $\mathrm{Ni}$ & $\mathrm{Zn}$ \\
\hline \multicolumn{12}{|l|}{ Ånäset (ASS) } \\
\hline An-50 & 50 & Clay & 4.2 & 0.11 & & & 3.9 & 38.9 & 158 & 10.3 & 34.8 \\
\hline An-80 & 80 & Clay & 3.7 & 0.16 & 0.1 & 2.1 & 4.3 & 38.5 & 176 & 11.5 & 39.8 \\
\hline An-120 & 120 & Clay & 3.6 & 0.22 & & & 3.9 & 34.8 & 166 & 10.2 & 36.4 \\
\hline An-180 & 180 & Clay & 6.6 & 0.69 & 0.1 & 2.3 & 7.9 & 33.7 & 349 & 19.2 & 59.1 \\
\hline \multicolumn{12}{|l|}{ Flarkbäck (ASS) } \\
\hline Fl-50 & 50 & Silty clay & 4.6 & 0.11 & & & 3.1 & 31.5 & 124 & 8.9 & 29.7 \\
\hline Fl-80 & 80 & Silty clay & 4.4 & 0.14 & 0.1 & 3.4 & 3.0 & 31.7 & 125 & 8.8 & 31.0 \\
\hline Fl-110 & 110 & Clay & 3.6 & 0.37 & & & 3.2 & 31.5 & 142 & 8.9 & 29.8 \\
\hline Fl-140 & 140 & Clay & 3.9 & 0.78 & & & 6.2 & 34.1 & 274 & 14.8 & 51.8 \\
\hline Fl-220 & 220 & Clay & 6.9 & 0.73 & 0.1 & 1.7 & 7.6 & 32.3 & 452 & 17.3 & 57.5 \\
\hline \multicolumn{12}{|c|}{ Vebomark Pond (Flooded ASS) } \\
\hline VePo-130 & 130 & Clay & 5.5 & 0.05 & & & 3.4 & 34.2 & 138 & 9.2 & 36.9 \\
\hline VePo-160 & 160 & Clay & 4.4 & 0.14 & 0.1 & 2.0 & 3.9 & 35.1 & 149 & 9.9 & 39.9 \\
\hline VePo-190 & 190 & Clay & 5.1 & 0.18 & & & 4.2 & 37.3 & 169 & 12.0 & 48.0 \\
\hline VePo-240 & 240 & Clay & 6.0 & 1.58 & & & 8.9 & 37.5 & 469 & 20.9 & 73.3 \\
\hline VePo-260 & 260 & Clay & 6.1 & 1.56 & 0.1 & 2.2 & 8.7 & 36.3 & 435 & 19.9 & 70.7 \\
\hline \multicolumn{12}{|c|}{ Vebomark (ASS) } \\
\hline Ve-50 & 50 & Silty clay & 4.8 & 0.01 & & & 3.4 & 32.3 & 149 & 9.0 & 33.7 \\
\hline Ve-80 & 80 & Silty clay & 4.5 & 0.03 & 0.1 & 0.8 & 4.2 & 39.3 & 186 & 10.6 & 41.0 \\
\hline Ve-110 & 110 & Clayey silt & 4.3 & 0.12 & & & 2.7 & 30.7 & 122 & 7.4 & 28.4 \\
\hline Ve-140 & 140 & Sandy silt & 4.9 & 0.13 & & & 5.0 & 18.2 & 86 & 13.4 & 26.3 \\
\hline Ve-160 & 160 & Sandy silt & 5.0 & 0.12 & & & 4.3 & 21.7 & 91 & 13.8 & 33.1 \\
\hline Ve-190 & 190 & Sandy silt & 5.8 & 0.07 & 0.0 & 0.1 & 2.8 & 14.1 & 70 & 8.9 & 24.8 \\
\hline \multicolumn{12}{|c|}{ Bygdeå (Non-ASS) } \\
\hline By-30 & 30 & Silty clay & 4.7 & 0.16 & & & 3.5 & 33.7 & 115 & 9.9 & 32.7 \\
\hline By-45 & 45 & Silty clay & 4.9 & 0.07 & & & 3.0 & 26.0 & 104 & 8.0 & 27.8 \\
\hline By-70 & 70 & Silty sand & 5.1 & 0.02 & 0.0 & 0.2 & 1.3 & 9.9 & 53 & 3.5 & 11.7 \\
\hline By-100 & 100 & Silty sand & 6.6 & 0.41 & & & 4.3 & 12.6 & 84 & 7.0 & 21.0 \\
\hline By-120 & 120 & Silty clay & 7.5 & 0.30 & 0.0 & 0.2 & 11.3 & 38.8 & 390 & 23.3 & 80.7 \\
\hline \multicolumn{12}{|c|}{ Kålaboda (Non-ASS) } \\
\hline Ka-50 & 50 & Clay & 5.4 & 0.02 & & & 4.4 & 35.3 & 202 & 10.3 & 39.3 \\
\hline Ка-80 & 80 & Clay & 5.1 & 0.02 & 0.1 & 0.5 & 5.2 & 37.0 & 231 & 12.7 & 48.8 \\
\hline Ка-110 & 110 & Clay & 5.6 & 0.01 & & & 6.4 & 38.0 & 258 & 15.2 & 56.8 \\
\hline Ка-120 & 120 & Clay & 6.2 & 0.05 & 0.0 & 0.3 & 13.9 & 36.1 & 388 & 25.9 & 92.8 \\
\hline
\end{tabular}



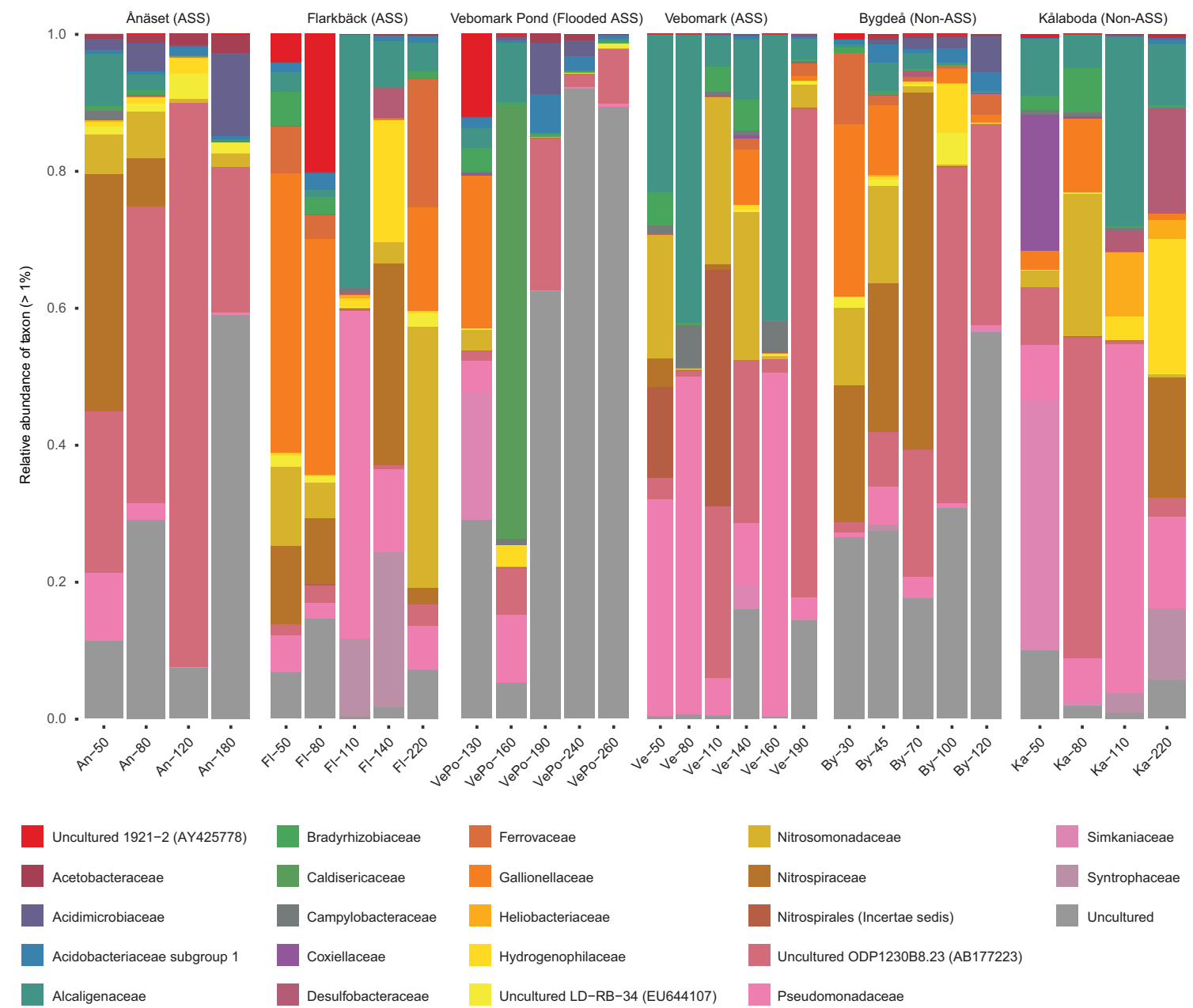

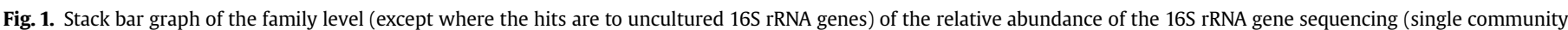
DNA extractions were performed). Only families with $>1 \%$ relative abundance are included.

an Australian coastal ASS study [24], no archaea were identified in the dominant $16 \mathrm{~S}$ rRNA gene sequences. This may be due to the typically increased incidence of archaea at the higher temperatures encountered in Australia compared to the boreal soils studied here. There were also large differences between the microbial community on the western Baltic Sea coast in this study compared to the eastern coastline [4]. For instance, the acidophilic ferrous iron and/or inorganic sulfur compound oxidizing Acidithiobacillus genus was lacking in this study but was identified in two reports on ASS on the eastern (Finnish) coastline $[4,10]$.

Few of the most abundant microbial families were consistently present in both the low pH Ånäset (An-80 and An-120) as well as the Flarkbäck (Fl-110 and Fl-140) communities (Fig. 2). This was confirmed by compositional principle coordinate analyses of the microbial populations (Fig. 3), also in reference to either $\mathrm{pH}$ or soil depth (data not shown). While $43.8 \%$ and $18.7 \%$ of the observed diversity could be explained by the first and second principal component, the analysis confirmed the weak influence of most measured chemical parameters on the microbial community, with exception of the concentration of sulfur in the soil. This parameter positively correlated with the occurrence of predicted heterotrophic acidophilic organisms of the Acidimicrobiacaea and Acidimicrobiales. The closest correlation however was observed to unassigned members of the Proteobacteria (Fig. 3), which could indicate their placement in sulfur-oxidizing acidophilic clades.
Nevertheless, the generally low predictive strength of the measured chemical parameters strongly suggests that low $\mathrm{pH}$ and high metal mobility were not the dominant factors that selected for the microbial communities. This is in contrast to findings in ASS on the eastern (Finnish) coastline [33]. Other factors that could play more important roles include availability of organic carbon and nutrients, the age of the ASS and consequently, the degree of sulfidic material oxidation.

As the Ånäset and Flarkbäck sites exhibited typical ASS soil profiles, these soils will be focused on in the microbiological analysis (Fig. 2 \& Supplementary Fig. 4). The most dominant 16S rRNA gene sequences in the $\mathrm{pH}<4.0$ Ånäset samples were most similar to the uncultured clone ODP1230B8.23 [39]. These OTUs included e.g. OTU_000013,_005741, and_000016 (Fig. 2 \& Supplementary Fig. 4) that also aligned to uncultured Halanaerobiales spp. that were identified from the extremely acidic Rio Tinto river [40] and acid mine drainage in Svalbard [41]. This suggested they were adapted to the acidic $\mathrm{pH}$ and metal rich conditions as well as to the low temperatures occurring in northern Sweden. A further family present in the An-80 and -120 samples was the Acidimicrobiaceae that included OTU_002215, _001883, and _000054 (totaling $13.9,5.6$, and $25.1 \%$ of the relative populations, respectively). These OTUs were most similar to an Acidimicrobiales sp. identified from an acid mine drainage at temperatures down to $9{ }^{\circ} \mathrm{C}[42]$. A third family from the Ånäset site at 50 and $80 \mathrm{~cm}$ soil 


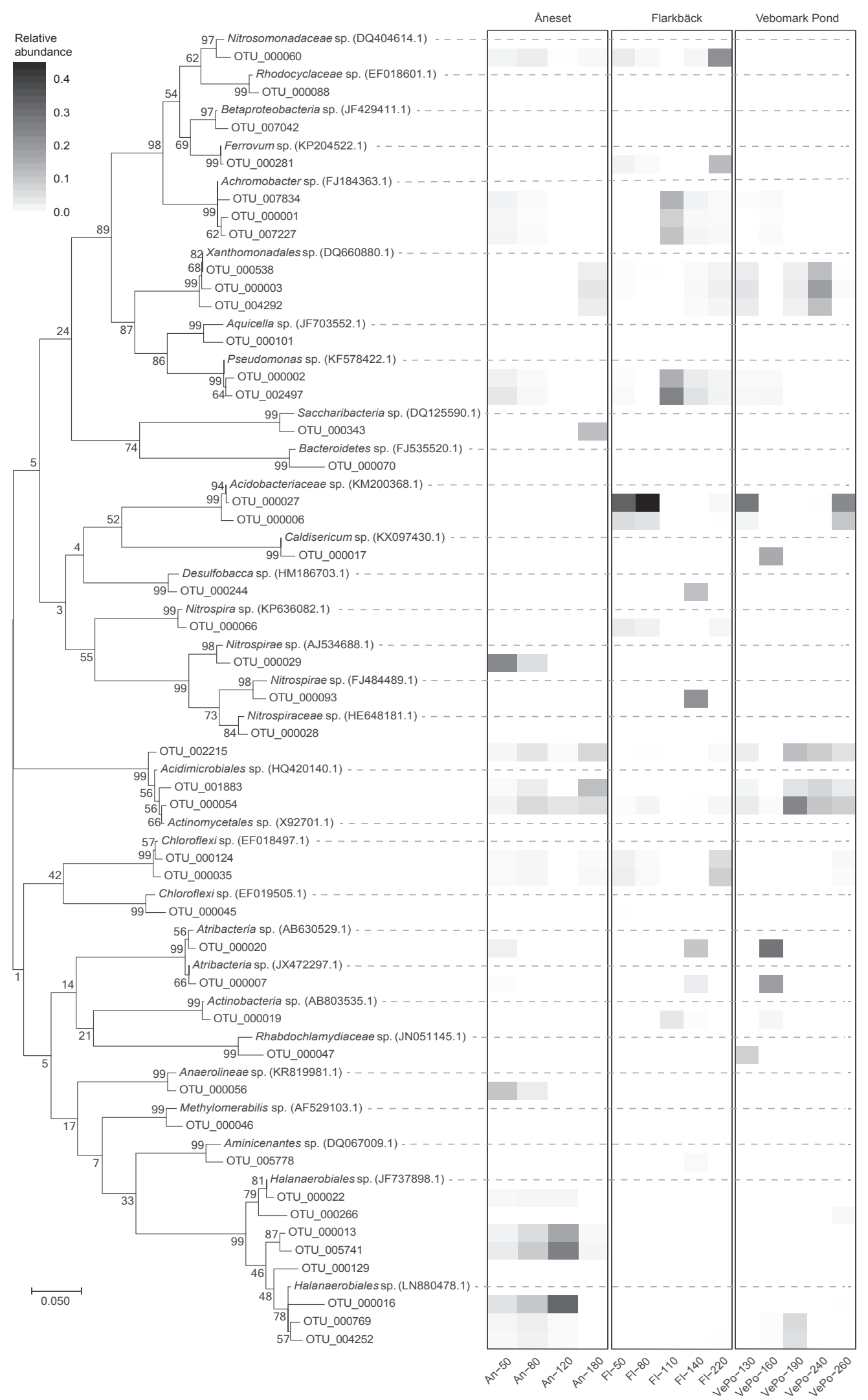

Fig. 2. Phylogenetic tree and heatmap showing the top OTUs (i.e. $\geq 10 \%$ relative abundance in at least one of the samples) derived from the $16 \mathrm{~S}$ rRNA gene analysis from the Ånäset (ASS), Flarkmark (ASS), and Vebomark Pond (Flooded ASS) samples. Reference sequences downloaded from NCBI Genebank have a dashed line in the heatmap. The scale bar represents nucleotide substitutions per site. The evolutionary history was inferred by using the Maximum Likelihood method and the highest log likelihood tree (-7832.1568) is shown that utilized a total of 427 positions in the final dataset. Bootstrap values are shown next to the branches. 


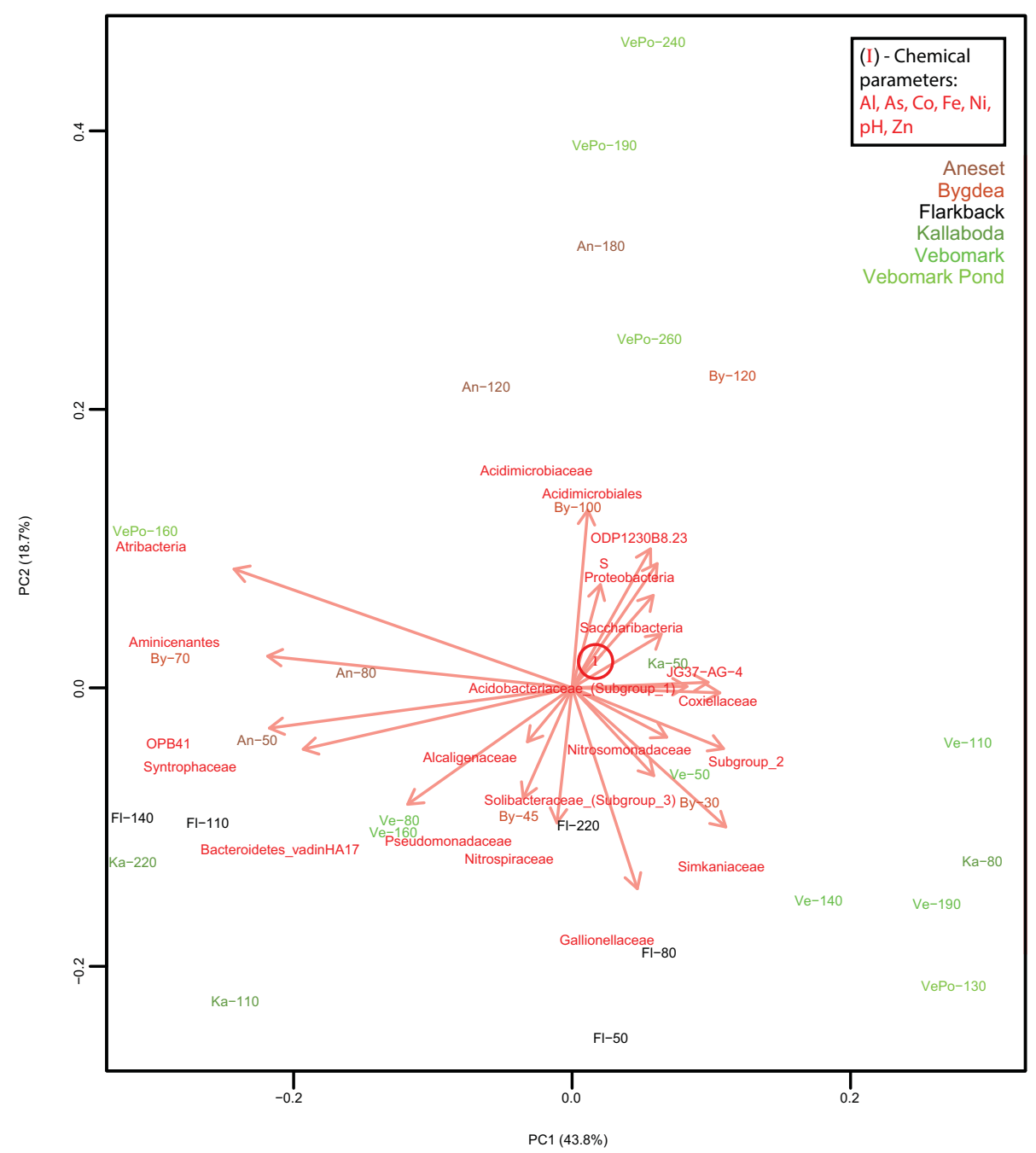

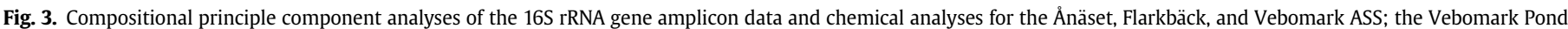

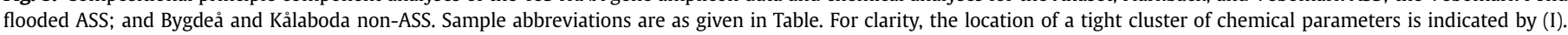

depths was the Nitrospiraceae (e.g. OTU_000029 constituting 24.1 and $5.7 \%$, of the respective relative communities). Members of this family are ubiquitous in oxic and anoxic soil environments and fulfill a wide range of metabolic functions [43]. The Nitrospiraceae include the acidophilic genus Leptospirillum [44] that is more commonly found at $\mathrm{pH}$ values of $<2.0$. The possible presence of Leptospirilli raises in question the existence of micro-niches of extreme acidity within the soil. Samples An-80 and An-120 also contain 16S rRNA gene sequences (e.g. OTU_001186,_000232, and _000051) that align with the ferrous iron oxidizing Gallionellaceae [45] that were also identified in Finnish ASS [4]. Finally, the Ånäset $\mathrm{pH}<4.0$ soils contained sequences that aligned with the Acetobacteraceae [46] that include several acidophilic phyla such as the Acidiphilium and the moderately acidophilic, low temperature genus Acidisoma.

The Flarkbäck soils at 110 and $140 \mathrm{~cm}(\mathrm{pH}<3.9)$ contained sequences from the Pseudomonadaceae [47] including OTU_000002 and 002497 that totaled 40.8 and $8.5 \%$ of the relative population in Fl-110 and -140 communities, respectively. These OTUs aligned with a Pseudomonas sp. isolated from a soil at $10^{\circ} \mathrm{C}$ suggesting they were adapted to the low temperature. A second abundant family in Fl-110 and -140 was the Alcaligenaceae (e.g. OTU_007834, _00001, and _007227) that are found in a variety of environments [48]. ASS with a $\mathrm{pH}<4.0$ from Flarkbäck also had 16S rRNA genes most similar to Ferrovaceae that are low temperature ferrous iron and sulfur compound oxidizing acidophiles [49] as well as the ferrous iron oxidizing Gallionellaceae [45]. The Fl-140 soil also had a large relative abundance of OTUs most similar to bacteria within the Nitrospiraceae (e.g. OTU_000093; 22.1\% of the relative abundance); the Syntrophaceae including OTU_000244 most similar to the sulfate reducing genus Desulfobacca with $12.0 \%$ of the relative population [50]; and the candidate phylum Atribacteria (e.g. OTU_000020; $10.7 \%$ of the relative population) identified from an Antarctic lake [51] suggesting it was adapted to the low temperature. The deepest Flarkbäck sample (Fl-220) had very different geochemical characteristics such as a higher $\mathrm{pH}$ and $\mathrm{Co}, \mathrm{Ni}, \mathrm{Zn}$, and Mn concentrations typical for PASS material. However, the relative proportions of OTUs aligning with ferrous iron and sulfur compound oxidizing Nitrosomonadaceae (OTU_000060; 9.5\%) and Ferrovaceae (OTU_000281; 5.4\%) raises the possibility that this soil depth was in the process of being oxidized into an ASS.

In contrast to the ASS profiles for the Ånäset and Flarkbäck sites, the other soils had typical geochemical characteristics for boreal zones. These samples had 16S rRNA genes assigned to the obligately 
intracellular Simkaniaceae found in eukaryotes [52] that may reflect a higher proportion of eukaryotes in the $\mathrm{pH}$ neutral soil. A second family present in several of the non-ASS soils was the Alcaligenaceae that are found in a range of environments. Finally, the non-ASS soil profiles had a comparably low proportion of uncultured clones without a phylogenetic assignment that highlights the need to carry out further work to identify community members associated with ASS.

\subsection{Comparison with the microbial community in the flooded ASS}

The trend of increasing 16S rRNA sequences most similar to uncultured clones was particularly strong in the Vebomark Pond samples (Fig. 1 \& Supplementary Fig. 3), potentially due to the deeper samples taken at this site. The VePo-160 sample had a high relative proportion of $16 \mathrm{~S}$ rRNA sequences that aligned with the Caldisericaceae that in the literature is represented by a single species that grows chemoheterotrophically via anaerobic reduction of sulfur compounds [53] that is consistent with the geochemical data indicating alkalinity-producing reduction reactions had occurred [54]. The dominant families in the deeper Vebomark pond soils aligned within the Acidimicrobiaceae such as OTU_002215, _001883, and _000054 that together made up $42.0 \%$ of the relative population in VePo-190 and were also present at lower proportions in VePo-240 and -290. These OTUs were also identified in the $\mathrm{pH}<4.0$ Ånäset soils and were most similar to uncultured clones identified from acid mine drainage. However, in the waterlogged and likely reduced conditions in the Vebomark Pond samples, the Acidimicrobiales related OTUs potentially grew via anaerobic ferric iron reduction [55] and could thereby have elevated the $\mathrm{pH}$ of the former ASS. Within the uncultured portion of the community, the VePo-240 soil contained OTUs (e.g. OTU_000538,_000003, and _004292) that aligned with a Xanthomonadales sp. identified from acid mine drainage. 16S rRNA gene sequences similar to Xanthomonadaceae identified from acid mine drainage were also enriched from ASS on the Finnish side of the Baltic Sea [4]. Finally, the Vebomark pond soils contained 16S rRNA gene sequences most similar to an Acidobacteriaceae sp. (such as OTU_000027 and_000006) that was in turn most similar to species typically found in $\mathrm{pH}$ neutral environments. The high relative proportion of acidophiles in the Vebomark pond soils supports the geochemical analyses showing that this soil was once oxidized. However, it should be noted that the $\mathrm{pH}$ in these soils were higher than the typical ASS at Ånäset and Flarkbäck and the increased $\mathrm{pH}$ may have inhibited the acidophiles from catalyzing further acid and metal release. Additional studies will need to be carried out to identify if the metal sulfides continue to oxidize and the acidophilic microbes are active at this remediated site.

\section{Conclusion}

Despite environmental concerns related to the release of metals and acid, the occurrence of acid sulfate soils has scientifically been largely neglected in boreal environments. The results of this study showed that Swedish acid sulfate soils are being oxidized, that this oxidation is likely catalyzed by acidophilic microorganisms, and that creating an anoxic environment by flooding an acid sulfate soil has begun to reverse the process of acid generation. However, in contrast to studies on the eastern Baltic coast, principal coordinate analysis does not indicate low $\mathrm{pH}$ and high metal concentrations to be the dominant factors shaping the microbial community. These data can be used to identify areas of acid sulfate soils and to help design strategies to mitigate their environmental impact in the northern Baltic area.

\section{Conflict of interest}

None.

\section{Acknowledgements}

The project was supported by the European Union via the Interreg Botnia-Atlantica program to the project 'Vatten och Människan i Landskapet (VIMLA)'. MÅ and MD thank Formas (contract 2018-00760) and the Geological Survey of Sweden (contract 36-1878/2017) for financial support.

\section{Appendix A. Supplementary data}

Supplementary data to this article can be found online at https://doi.org/10.1016/j.resmic.2019.06.002.

\section{References}

[1] Yli-Halla M, Virtanen S, Mäkelä M, Simojoki A, Hirvi M, Innanen S, et al. Abundant stocks and mobilization of elements in boreal acid sulfate soils. Geoderma 2017;308(Suppl. C):333-40.

[2] Boman A, Fröjdö S, Backlund K, Åström ME. Impact of isostatic land uplift and artificial drainage on oxidation of brackish-water sediments rich in metastable iron sulfide. Geochim Cosmochim Acta 2010;74:1268-81.

[3] Österholm P, Åström M. Quantification of current and future leaching of sulfur and metals from Boreal acid sulfate soils, western Finland. Aust J Soil Res 2004; $42: 547-51$

[4] Wu X, Wong ZL, Sten P, Engblom S, Osterholm P, Dopson M. Microbial community potentially responsible for acid and metal release from an Ostrobothnian acid sulfate soil. FEMS Microbiol Ecol 2013:84:555-63.

[5] Nordmyr L, Aström M, Peltola P. Metal pollution of estuarine sediments caused by leaching of acid sulphate soils. Estuar Coast Shelf Sci 2008;76: $141-52$.

[6] Nordmyr L, Boman A, Astrom M, Österholm P. Estimation of leakage of chemical elements from boreal acid sulphate soils based on a geochemical and hydrochemical approach. Boreal Environ Res 2006;11:261-71.

[7] Roos M, Åström M. Gulf of Bothnia receives high concentrations of potentially toxic metals from acid sulphate soils. Boreal Environ Res 2006;11:383-388.

[8] Högfors-Rönnholm E, Christel S, Dalhem K, Lillhonga T, Engblom S, Österholm P, et al. Chemical and microbiological evaluation of novel chemical treatment methods for acid sulfate soils. Sci Total Environ 2018;625:39-49.

[9] Joukainen S, Yli-Halla M. Environmental impacts and acid loads from deep sulfide layers of two well-drained acid sulfate soils in western Finland. Agric Ecosyst Environ 2003;95:297-309.

[10] Wu X, Sten P, Engblom S, Nowak P, Österholm P, Dopson M. Impact of mitigation strategies on microbial community from an Ostrobothnian acid sulfate soil. Sci Total Environ 2015:526:215-21.

[11] Öborn I. Properties and classification of some acid sulfate soils in Sweden. Geoderma 1989;45:197-219.

[12] Sohlenius G, Öborn I. Geochemistry and partitioning of trace metals in acid sulphate soils in Sweden and Finland before and after sulphide oxidation. Geoderma 2004;122:167-75.

[13] Öhlander B, Nordblad F, Lax K, Ecke F, Ingri J. Biogeochemical mapping of stream plants to trace acid sulphate soils: a comparison between water geochemistry and metal content in macrophytes. Geochem Explor Environ Anal 2013;14:85-94.

[14] Sohlenius G, Bastani M, Persson L, Lax K. On the recognition of areas with problematic sulphidic sediments using multi-disciplinary data. Environ Geol 2009;56:973-84.

[15] Chen L, Huang L, Méndez-García C, Kuang J, Hua Z, Liu J, et al. Microbial communities, processes and functions in acid mine drainage ecosystems. Curr Opin Biotechnol 2016;38:150-8.

[16] Johnson DB. Biomining - biotechnologies for extracting and recovering metals from ores and waste materials. Curr Opin Biotechnol 2014:30:24-31.

[17] Schippers A, Sand W. Bacterial leaching of metal sulfides proceeds by two indirect mechanisms via thiosulfate or via polysulfides and sulfur. Appl Environ Microbiol 1999;65:319-21.

[18] Hallberg KB, Gonzalez-Toril E, Johnson DB. Acidithiobacillus ferrivorans, sp. nov.; facultatively anaerobic, psychrotolerant iron-, and sulfur-oxidizing acidophiles isolated from metal mine-impacted environments. Extremophiles 2010;14:9-19.

[19] Christel S, Fridlund J, Buetti-Dinh A, Buck M, Watkin EL, Dopson M. RNA transcript sequencing reveals inorganic sulfur compound oxidation pathways in the acidophile Acidithiobacillus ferrivorans. FEMS Microbiol Letts 2016;363: fnw057.

[20] Kupkaa D, Liljeqvist M, Nurmic P, Puhakkac JA, Tuovinen OH, Dopson M. Oxidation of elemental sulfur, tetrathionate, and ferrous iron by the psychrotolerant Acidithiobacillus strain SS3. Res Microbiol 2009;160:767-74. 
[21] Christel S, Fridlund J, Watkin EL, Dopson M. Acidithiobacillus ferrivorans SS3 presents little RNA transcript response related to cold stress during growth at $8{ }^{\circ} \mathrm{C}$ suggesting it is a eurypsychrophile. Extremophiles 2016;20:903-13.

[22] Liljeqvist M, Valdes J, Holmes DS, Dopson M. Draft genome of the psychrotolerant acidophile Acidithiobacillus ferrivorans SS3. J Bacteriol 2011;193: 4304-5.

[23] Barlund I, Tattari S, Yli-Halla M. Measured and simulated effects of sophisticated drainage techniques on groundwater level and runoff hydrochemistry in areas of boreal acid sulphate soils. Agricult Food Sci 2005:14:98-111.

[24] Ling YC, Bush R, Grice K, Tulipani S, Berwick L, Moreau JW. Distribution of iron- and sulfate-reducing bacteria across a coastal acid sulfate soil (CASS) environment: implications for passive bioremediation by tidal inundation. Front Microbiol 2015;6(624). https://doi.org/10.3389/fmicb.2015.00624.

[25] Alawi M, Schneider B, Kallmeyer J. A procedure for separate recovery of extraand intracellular DNA from a single marine sediment sample. J Microbiol Methods 2014;104:36-42.

[26] Högfors-Rönnholm E, Christel S, Engblom S, Dopson M. Indirect DNA extraction method suitable for acidic soil with high clay content. MethodsX 2018;5:136-40. https://doi.org/10.1016/j.mex.2018.02.005.

[27] Herlemann DP, Labrenz M, Jurgens K, Bertilsson S, Waniek JJ, Andersson AF. Transitions in bacterial communities along the $2000 \mathrm{~km}$ salinity gradient of the Baltic Sea. ISME J 2011;5:1571-9.

[28] Hugerth LW, Wefer HA, Lundin S, Jakobsson HE, Lindberg M, Rodin S, et al. DegePrime, a program for degenerate primer design for broad-taxonomicrange PCR in microbial ecology studies. Appl Environ Microbiol 2014;80: 5116-23.

[29] Lindh MV, Figueroa D, Sjöstedt J, Baltar F, Lundin D, Andersson A, et al. Transplant experiments uncover Baltic Sea basin-specific responses in bacterioplankton community composition and metabolic activities. Fron Microbiol 2015;6. https://doi.org/10.3389/fmicb.2015.00223.

[30] Edgar RC. UPARSE: highly accurate OTU sequences from microbial amplicon reads. Nat Methods 2013;10:996-8.

[31] Quast C, Pruesse E, Yilmaz P, Gerken J, Schweer T, Yarza P, et al. The SILVA ribosomal RNA gene database project: improved data processing and webbased tools. Nucleic Acids Res 2013;41(Database issue):D590-6.

[32] McMurdie PJ, Holmes S. phyloseq: an R package for reproducible interactive analysis and graphics of microbiome census data. PLoS One 2013:8:e61217.

[33] Högfors-Rönnholm E, Christel S, Dalhem K, Lillhonga T, Engblom S, Österholm P, et al. Chemical and microbiological evaluation of novel chemical treatment methods for acid sulfate soils. Sci Total Environ 2017;625:39-49.

[34] Kumar S, Stecher G, Tamura K. MEGA7: molecular evolutionary genetics analysis Version 7.0 for bigger datasets. Mol Biol Evol 2016;33:1870-4.

[35] Boman A, Astrom M, Frojdo S. Sulfur dynamics in boreal acid sulfate soils rich in metastable iron sulfide-The role of artificial drainage. Chem Geol 2008;255: $68-77$.

[36] Åström M. Partitioning of transition metals in oxidised and reduced zones of sulphide-bearing fine-grained sediments. Appl Geochem 1998;13:607-17.

[37] Lopez-Fernandez M, Åström M, Bertilsson S, Dopson M. Depth and dissolved organic carbon shape microbial communities in surface influenced but not ancient saline terrestrial aquifers. Front Microbiol 2018;9:2880.

[38] Lopez-Fernandez M, Broman E, Turner S, Wu X, Bertilsson S, Dopson M. Investigation of viable taxa in the deep terrestrial biosphere suggests high rates of nutrient recycling. FEMS Microbiol Ecol 2018;94(8).

[39] Inagaki F, Nunoura T, Nakagawa S, Teske A, Lever M, Lauer A, et al. Biogeographical distribution and diversity of microbes in methane hydrate-bearing deep marine sediments on the Pacific Ocean Margin. Proc Natl Acad Sci U S A 2006;103(8):2815-20.
[40] Garcia-Moyano A, Gonzalez-Toril E, Aguilera A, Amils R. Comparative microbial ecology study of the sediments and the water column of the Rio Tinto, an extreme acidic environment. FEMS Microbiol Ecol 2012;81:303-14.

[41] Garcia-Moyano A, Austnes AE, Lanzen A, Gonzalez-Toril E, Aguilera A, Ovreas L. Novel and unexpected microbial diversity in acid mine drainage in Svalbard $\left(78^{\circ} \mathrm{N}\right)$, revealed by culture-independent approaches. Microorganisms 2015;3:667-94.

[42] Brown JF, Jones DS, Mills DB, Macalady JL, Burgos WD. Application of a depositional facies model to an acid mine drainage site. Appl Environ Microbiol 2011;77:545-54.

[43] Daims H. The family Nitrospiraceae. In: Rosenberg E, DeLong EF, Lory S, Stackebrandt E, Thompson F, editors. The prokaryotes. Other major lineages of bacteria and the archaea. Berlin Heidelberg: Springer; 2014.

[44] Dopson M. Physiological and phylogenetic diversity of acidophilic bacteria. In: Quatrini R, Johnson DB, editors. Acidophiles: Life in extremely acidic environments. Caister Academic Press; 2016. p. 79-92.

[45] Hallbeck L, Pedersen K. The family Gallionellaceae. In: Rosenberg E, DeLong EF, Lory S, Stackebrandt E, Thompson F, editors. The prokaryotes: alphaproteobacteria and betaproteobacteria. Berlin, Heidelberg: Springer Berlin Heidelberg; 2014. p. 853-8.

[46] Kersters K, Lisdiyanti P, Komagata K, Swings J. The family Acetobacteraceae: the genera Acetobacter, Acidomonas, Asaia, Gluconacetobacter, Gluconobacter, and Kozakia. In: Dworkin M, Falkow S, Rosenberg E, Schleifer KH, Stackebrandt E, editors. The prokaryotes: Volume 5: Proteobacteria: alpha and beta subclasses. New York, NY: Springer New York; 2006. p. 163-200.

[47] Palleroni NJ. Introduction to the family Pseudomonadaceae. In: Starr MP, Stolp H, Truper HG, Balows A, Schlegel HG, editors. The prokaryotes: a handbook on habitats, isolation, and identification of bacteria. Berlin, Heidelberg: Springer Berlin Heidelberg; 1981. p. 655-65.

[48] Austin B. The family Alcaligenaceae. In: Rosenberg E, DeLong EF, Lory S, Stackebrandt E, Thompson F, editors. The prokaryotes: alphaproteobacteria and betaproteobacteria. Berlin, Heidelberg: Springer Berlin Heidelberg; 2014. p. $729-57$.

[49] Johnson DB, Hallberg KB, Hedrich S. Uncovering a microbial enigma: Isolation and characterization of the streamer-generating, iron-oxidizing, acidophilic bacterium "Ferrovum myxofaciens". Appl Environ Microbiol 2014:80:672-80.

[50] Stams AJM, Oude Elferink SJWH, Desulfobacca. Bergey's manual of systematics of archaea and bacteria. John Wiley \& Sons, Ltd; 2015.

[51] Nakai R, Abe T, Baba T, Imura S, Kagoshima H, Kanda H, et al. Microflorae of aquatic moss pillars in a freshwater lake, East Antarctica, based on fatty acid and 16S rRNA gene analyses. Polar Biol 2012;35:425-33.

[52] Everett KDE. The family Simkaniaceae. In: Rosenberg E, DeLong EF, Lory S, Stackebrandt E, Thompson F, editors. The prokaryotes: other major lineages of bacteria and the archaea. Berlin, Heidelberg: Springer Berlin Heidelberg. 2014. p. 891-906.

[53] Mori K, Fujita N. The family Caldisericaceae. In: Rosenberg E, DeLong EF, Lory S, Stackebrandt E, Thompson F, editors. The prokaryotes: other major lineages of bacteria and the archaea. Berlin, Heidelberg: Springer Berlin Heidelberg; 2014. p. 489-92.

[54] Sanchez-Andrea I, Sanz JL, Bijmans MFM, Stams AJM. Sulfate reduction at low pH to remediate acid mine drainage. J Hazard Mater 2014;269(Suppl. C): 98-109.

[55] Bridge TAM, Johnson DB. Reduction of soluble iron and reductive dissolution of ferric iron-containing minerals by moderately thermophilic iron-oxidizing bacteria. Appl Environ Microbiol 1998;64:2181-6. 